\title{
Assessing the Hepatotoxicity of Industrial Leachate; Histopathology and Heavy Metal Contents in Liver of Wistar Rats
}

\author{
Muhammad Babar Khawar ${ }^{1}$, Rabia Mehmood ${ }^{1}$, Muddasir Hassan Abbasi2,* and Nadeem Sheikh1,2,* \\ ${ }^{1}$ Cell \& Molecular Biology Lab, Department of Zoology, University of the Punjab, Lahore, Pakistan \\ ${ }^{2}$ Centre for Applied Molecular Biology (CAMB), University of the Punjab, Lahore, Pakistan
}

\section{ABSTRACT}

The process of paper production requires a huge quantity of water and energy and in turn contributes a number of effluents in the form of phenolics, toxic organic compounds and heavy metals in wastewater (leachate). The present investigation was aimed to assess the toxic effects of leachate on liver micro-architecture and heavy metal elements of the liver. Eighteen (18) healthy male Wistar rats $(240 \pm 10 \mathrm{~g})$ were selected and acclimatized prior to experimental treatment. These rats were randomly divided into three groups viz, Control group (received $4 \mathrm{ml} / \mathrm{kg}$ normal saline), Group $1(4 \mathrm{ml} / \mathrm{kg}$ leachate) and Group $2(4 \mathrm{ml} / \mathrm{kg} 1: 10$ diluted leachate). All the animals were dissected and liver tissues were collected and processed accordingly after $24 \mathrm{~h}$ of leachate treatment. High level of cadmium and chromium were found in Group 1 as compared to the control group upon liver metal contents analysis found out by flame atomic absorption spectrometer. A clear disruption of micro-architecture of the liver, congested sinusoids, damaged central vein, and perturbed morphology was observed in Group-1 as revealed by $\mathrm{H}$ \& $\mathrm{E}$ staining. Moreover, loss of polarity, congestion, and disruption of hepatocytes and pronounced vacuolization in the cytoplasm was observed in Group 2 compared to control sections. On the basis of above findings, it can be concluded that paper industry leachate is highly toxic and its intraperitoneal injection results in hepatotoxicity that not only affects the hepatic micro-architecture but also results in perturbed liver metal contents. Therefore, proper treatment of such wastewater is required before its disposal.

$\begin{array}{lll}\text { Keywords } & \text { *Address of Correspondence } & \text { Article info. } \\ \text { Heavy metals, Histopathology, Leachate, } & \text { s_nadeem77@yahoo.com } & \text { Received: September 16, 2018 } \\ \text { Toxicity, Wastewater. } & \text { muddygcs@gmail.com } & \text { Accepted: October 26, 2018 }\end{array}$

Cite this article: Khawar MB, Mehmood R, Abbasi MH, Sheikh N. Assessing the Hepatotoxicity of Industrial Leachate; Histopathology and Heavy Metal Contents in Liver of Wistar Rats. RADS Funding Source: Nil Conflict of Interest: Nil

J. Biol. Res. Appl. Sci. 2018; 9(2): 82-87.

This is an Open Access article distributed under the terms of the Creative Commons Attribution License (http://creativecommons.org/licenses/by/4.0), which permits unrestricted use, distribution, and reproduction in any medium, provided the original work is properly cited.

\section{INTRODUCTION}

Pulp and paper industry is involved in the spread of pollution because of the toxicity it poses to the environment. This industry utilizes a large quantity of lignocelluloses materials as well as a large amount of water as a raw material for paper production and in turn results in the discharge of a large quantity of effluents $1 ; 2$. These effluents are problematic because of their biochemical oxygen demand (BOD), absorbable organic halides (AOX), dark coloration, chemical oxygen demand (COD), pH and large amounts of suspended solids (SS).
The early stage of the paper production is pulping which is a chief pollution source and results in the processed material. A significant amount of wastewater is produced at various stages of pulping. Firstly, mechanical pulping results in $90-95 \%$ of the yield of the pulp but the resultant pulp is highly colored, and of poor quality due to presence of short fibers in it. Chemical pulping involves some appropriate chemicals with suitable media (alkaline or acidic) are used to process wood chips at a high temperature and pressure within an aqueous solution 
which converts the wooden chips into a fibrous mass. Chemical pulping results in $40-50 \%$ pulp yield of the total wood utilized ${ }^{3}$.

Alkaline medium (Kraft process) is required to process the woodchips, solutions of sodium hydroxide $(\mathrm{NaOH})$ commonly called caustic soda and sodium sulfide $\left(\mathrm{NaS}_{2}\right)$ are used. On the other hand, acidic medium (Sulfite process) involves the use of certain acids like a combination of sulfurous acid $\left(\mathrm{H}_{2} \mathrm{SO}_{3}\right)$ and some other compounds like bisulfide ions $\left(\mathrm{HSO}_{3}^{-}\right)$to dissolve the lignin component.

These effluents also contain significant amounts of some highly toxic chlorinated compounds i.e. chlorinated hydrocarbon, lignosulphonic acids, chlorinated phenols and some resin acids etc. These chlorinated compounds react with lignin and some of its derivatives resulting in some very strong toxic compounds $4 ; 5$.

Most of the arbitrarily produced organo-chlorinated compounds during the process of pulp bleaching are highly noxious xenobiotics which remain un-degraded for a longer period of time in the environment. If these effluents are discharged to a hypoxic environment or anaerobic water the condition often became worse because of the high toxicity and lipophilic abilities of these xenobiotics upon methylation of chlorinated organic compounds by certain species of anaerobic bacteria. Unluckily, this high lipophilicity made them extremely soluble in fats of higher animals.

If any of this methylated chlorinated compound is accidentally ingested by an animal species i.e. fowl or fish, it gets deposited in their adipose tissues rather being completely metabolized and excreted through urine, it gradually becomes more and more concentrated (bioaccumulation) as is carried to the higher trophic levels in the food chain ${ }^{6}$. So, the present study was aimed to assess the hepatotoxicity of paper industry wastewater by analyzing the heavy metal contents and histopathology of the liver.

\section{MATERIAL AND METHOD}

\section{Animals}

Healthy Wistar rats of Eight (8) weeks of age weighing about $240 \pm 10 \mathrm{~g}$ were obtained from the Department of Zoology, University of Punjab (Lahore-Pakistan), housed in a room of animal house under controlled conditions with temperature $\left(22 \pm 1^{\circ} \mathrm{C}\right)$, humidity and light (12-h light/ dark cycles) with fresh water and food (Rat chow) available ad libitum throughout the course of study period. Procedures involving animals and their care were conducted in conformity with international laws and policies.

\section{Experimental Methodology and Animal Groupings}

Eighteen (18) healthy male Wistar rats weighing about $240 \pm 10 \mathrm{~g}$ were taken and randomly divided into three groups i.e. Control, Group 1 \& Group 2. Four (4) $\mathrm{ml} / \mathrm{kg}$ leachate was injected intraperitoneally to Group-1 while Group-2 received the same quantity of 1:10 diluted leachate. While control Group received same quantity of normal saline. Animals were euthanized and sacrificed after 24 hours of the leachate induction. Liver tissues of all the animals were excised and processed accordingly for further studies.

\section{Determination of Liver Metals Contents}

To reduce the chances of contamination, all the materials and chemicals used in the experiment were properly washed with $\mathrm{ddH}_{2} \mathrm{O}$, and a sterilized stainless steel scalpel was used to slice the hepatic tissues. Before carrying out the analysis, sample tissue $(1 \mathrm{~g})$ was taken from each liver specimen of control and both the experimental groups. Wet digestion method was adopted for the digestion of samples to determine heavy metal contents. Briefly, hepatic tissues were placed in a digestion flask with $7 \mathrm{ml}$ of conc. Nitric acid $\left(\mathrm{HNO}_{3}\right)$ and 1 $\mathrm{ml}$ of Hydrogen peroxide $\left(\mathrm{H}_{2} \mathrm{O}_{2}\right)$. After that, the flasks were placed on a hot plate for about 4-5 hours for complete digestion. Then, they were cooled down to room temperature. The remaining material was then filtered and diluted to make the final volume $15 \mathrm{ml}$. Then the analysis of each sample was carried out for two heavy metals viz, cadmium and chromium by using flame emission atomic absorption spectrometry.

\section{H \& E Staining}

$H \& E$ staining was carried out as follows: De-paraffinized slides were dipped in hematoxylin working solution for about 1.5 min followed by rinsing thoroughly with deionized $\mathrm{H}_{2} \mathrm{O}$ and then dehydration was carried out with 
$70 \%$ and $90 \%$ ethanol for 5 min each. Slides were subsequently stained with working eosin solution for 3-5 min and then rinsed with de-ionized water followed by a rapid dehydration through alcohol and xylene. Finally, the sections were subjected to microscopy to capture the images.

\section{Ethical Statement}

The experimental procedure and methodologies were approved by the ethical committee of the Department of Zoology, University of the Punjab, Lahore, Pakistan.

\section{Statistical Analysis}

All the data reported are means \pm SEM and were statistically calculated by using Prism Graph pad 5 software (San Diego, CA). One-way ANOVA was used to find out the statistical significance with $P<0.05$ considered significant.

\section{RESULTS}

\section{Cadmium and Chromium Liver Contents}

Cadmium, and chromium level in the liver of both the experimental groups, showed statistically significant alterations compared to control. Cadmium level showed a significant positive change and was measured as 102.3 $\mathrm{mg} / \mathrm{kg}$ in Group 1 while a significant negative change with $6.75 \mathrm{mg} / \mathrm{kg}$ was noted in Group $2(\mathrm{P}<0.0001)$ compared to control $42.6 \mathrm{mg} / \mathrm{kg}$. On the other hand, for chromium, a significant increase of $136.5 \mathrm{mg} / \mathrm{kg}$ was observed in Group 1 while Group 2 showed a decrement with $2.4 \mathrm{mg} /$ $\mathrm{kg}$ as compared to control $4.05 \mathrm{mg} / \mathrm{kg}(\mathrm{P}<0.0001)$ (Table 1) (Fig. 1)
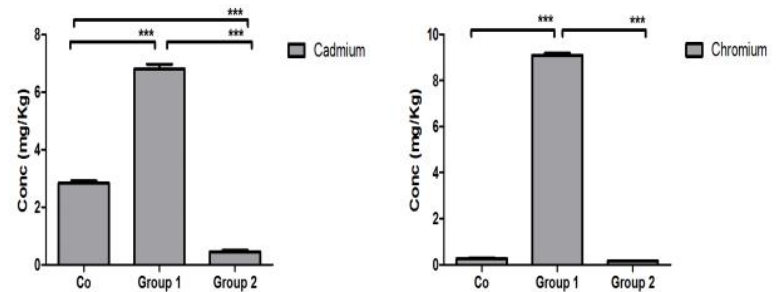

Fig. 1: Level of metal contents of cadmium and chromium in liver tissues.

Cadmium level was found to be increased significantly in Group 1 while it was decreased in Group 2 as compared to the control $(P<0.0001)$. A similar trend was observed in chromium levels in Group $1(\mathrm{P}<0.0001)$, while Group 2 showed no significant alterations compared to control. The results are representative of three animal series $n=3$ (mean \pm S.E.M.).

Table 1: Concentration of different heavy metals in liver tissues digested in $\mathrm{HNO}_{3}$ and $\mathrm{H}_{2} \mathrm{O}_{2}$ (7:1).

\begin{tabular}{|c|c|c|c|c|c|c|c|}
\hline Samples & Animals & $\begin{array}{l}\text { Concentrations } \\
\text { of } \mathrm{Cd}(\mathrm{mg} / \mathrm{L})\end{array}$ & $\begin{array}{c}\text { Average } \\
\text { (mg/L) }\end{array}$ & $\begin{array}{l}\text { Average } \\
\text { Cd } \\
\text { contents } \\
\text { in Liver } \\
\text { (mg/kg) }\end{array}$ & $\begin{array}{l}\text { Concentrations } \\
\text { of } \mathrm{Cr}(\mathrm{mg} / \mathrm{L})\end{array}$ & $\begin{array}{c}\text { Average } \\
\text { (mg/L) }\end{array}$ & $\begin{array}{l}\text { Average Cr } \\
\text { Contents in } \\
\text { Liver (mg/kg) }\end{array}$ \\
\hline \multirow{3}{*}{ Control } & $\mathrm{C} 1$ & 2.87 & \multirow{3}{*}{2.84} & \multirow{3}{*}{42.6} & 0.21 & \multirow{3}{*}{0.27} & \multirow{3}{*}{4.05} \\
\hline & $\mathrm{C} 2$ & 2.94 & & & 0.30 & & \\
\hline & C3 & 2.72 & & & 0.29 & & \\
\hline \multirow{3}{*}{ Group 1} & D1 & 6.49 & \multirow{3}{*}{6.82} & \multirow{3}{*}{$102.3^{* * *}$} & 8.96 & \multirow{3}{*}{9.10} & \multirow{3}{*}{$136.5^{* * *}$} \\
\hline & $\mathrm{D} 2$ & 6.95 & & & 9.27 & & \\
\hline & D3 & 7.01 & & & 9.06 & & \\
\hline \multirow{3}{*}{ Group 2} & E1 & 0.38 & \multirow{3}{*}{0.45} & \multirow{3}{*}{$6.75^{\star * *}$} & 0.13 & \multirow{3}{*}{0.16} & \multirow{3}{*}{2.4} \\
\hline & E2 & 0.45 & & & 0.15 & & \\
\hline & E3 & 0.53 & & & 0.19 & & \\
\hline
\end{tabular}




\section{Histopathological Examination}

Microscopic examinations were carried out using the microscope (Olympus VANOX), which showed various cellular changes in $\mathrm{H}$ \& $\mathrm{E}$ stained liver sections.

In the control H\&E stained sections, no pathological abnormalities were seen and sections looked normal with regular cellular architecture. The hepatocytes had intact cytoplasm, normal sinusoidal spaces and central vein (Fig. 2). The administration of leachate in rats led to disruption in general micro-architecture of the hepatic tissue. Sections from Group 1 showed thickening of epithelial cells surrounding the central vein, ruptured central vein, congestion of sinusoids, severe necrosis in some hepatocytes and a slight degeneration of a few hepatocytes (Fig. 3). While sections of Group 2 showed a disturbed architecture characterized with edema of hepatocytes, vacuolization, and degeneration in some hepatocytes but central vein remain intact (Fig. 4).

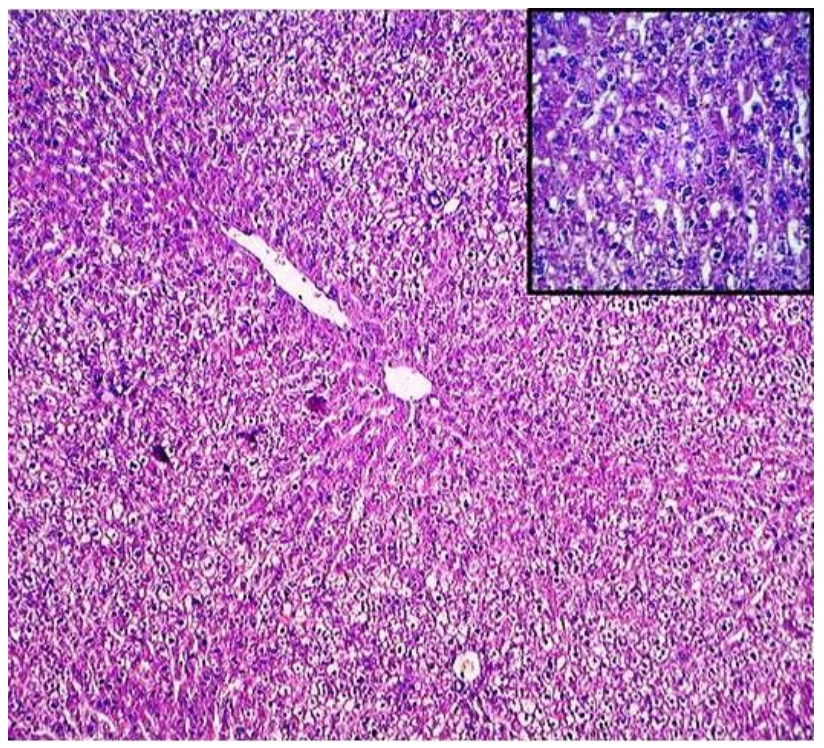

Fig. 2: H\&E stained section of control. Hematoxylin \& Eosin stained liver section of Control group showing intact micro-architecture and no sign of pathological anomaly.

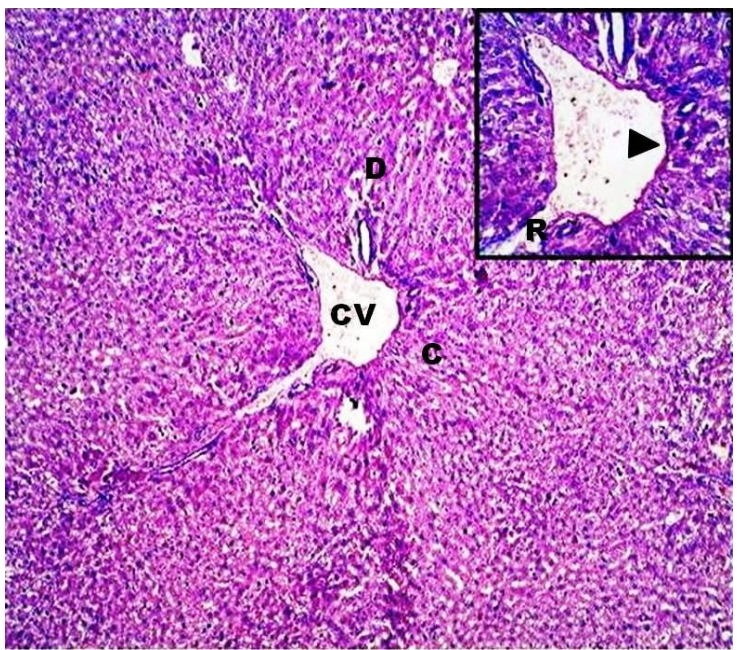

Fig. 3: H\&E stained section of Group 1. Hematoxylin \& Eosin stained liver section of Group 1 showing a disturbed micro-architecture with clear signs of a pathological anomaly. Section showing a congestion of sinusoids (C) and degeneration of some hepatocytes (D). Moreover in the enlarged view arrowhead is showing the thickening of basement membrane and a ruptured central vein can also be observed (R).

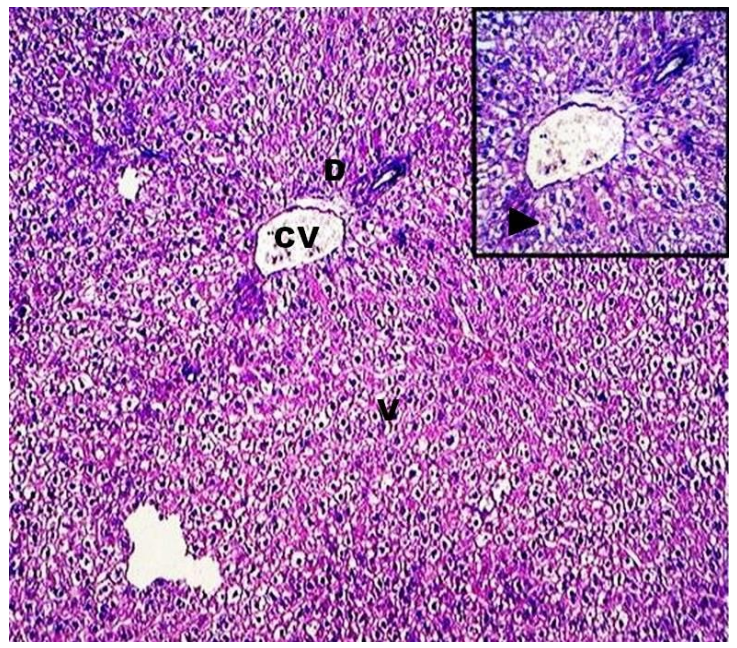

Fig. 4: H\&E stained section of Group 2. Hematoxylin \& Eosin stained liver section of Group 2 showing an abnormal micro-architecture while central vein (CV) remains intact with some clear signs of pathological problems. Section showing an extensive vacuolization (V) and degeneration of some hepatocytes (D). Enlarged view showing the edema of hepatocytes represented by an arrowhead. 


\section{DISCUSSION}

Liver, kidney, and gills are some of the metabolically active organs which are prime sites of heavy metal accumulation because of their functions ${ }^{7}$. Previous data revealed the role of the liver as a pivotal organ primarily involved in bio-transformations, redistribution of certain materials, storage of various useful as well as harmful substances, detoxification and many metabolic activities 8,9. Animals exposed to cadmium can accumulate this metal in various organs of the body primarily in the livers and kidneys because of the presence of free protein-thiol group which is responsible for a strong fixation and subsequent bioaccumulation of heavy metals. Despite very efficient excretory mechanism for the elimination of such heavy metals, vertebrates are unable to develop these mechanisms, during the course of evolution, to the extent necessary for today's anthropogenic sources of pollution ${ }^{10}$. Liver cadmium and chromium showed a significant increase in Group 1 compared to control. This increase in heavy metal contents is alarming because of their toxicity and interference with many important biological phenomena. Increased level of cadmium and chromium in the current study are clearly reflective of the effect of leachate induction resulting in bioaccumulation of these heavy metals.

Liver, one of the largest glands of the body, absorbs the nutrients from the small intestine and stored them as glycogen. In addition to it, the liver is also involved in the biosynthesis of a variety of plasma proteins and in the detoxification and neutralization of various exogenous toxins. So keeping in view the above-said roles, the hepatic cells are one of the highly active cells having eosinophilic cytoplasm and euchromatin nucleus.

The capillary plexus of hepatic sinusoids is responsible for the transportation of materials between blood and liver tissue ${ }^{11}$ and as hepatocytes are continuously exposed to the toxic substances in the blood so majorly these cells could be affected by these noxious substances.

In the current study, leachate induction led to prominent alterations in the microarchitecture of the liver tissues in both studied groups which are obvious from the H \& E stained histologic sections of the liver. Similar changes were observed by Ortiz et al., (1994) in the liver of chicks and rats after they were fed with diets high in tannins extracted from faba bean (Vicia faba). Ortiz et al., (1994) observed extensive vacuolization of hepatocytes, degeneration as well as marked eosinophilia ${ }^{12}$. Similarly, Emiola et al., (2007) observed severe degeneration of hepatocytes, congestion of sinusoids, as well as an extensive coagulative necrosis in chickens fed with raw, dehulled, and aqueous and dry-heated kidney bean meals ${ }^{13}$. Histological findings of the current study are in accordance with the results of the above studies because similar changes have been observed in Group 1 and Group 2 after the induction of leachate intraperitoneally.

\section{CONCLUSION}

So, it is recommended that before disposal of wastewater in water bodies or onto land, the characteristic dark color and toxic components especially phenols and chlorinated compounds must be eliminated or minimized to the levels below the discharge limits.

\section{Acknowledgements}

The authors are thankful to the Vice Chancellor, University of the Punjab, Lahore, Pakistan for providing financial support to publish the article.

\section{Competing Interests Statement for the Authors}

The authors declare that they have no conflicts of interests.

\section{REFERENCES}

1. Sumathi S, Hung YT. Treatment of pulp and paper mill wastes. In: Wang LK, Hung Y-T, Lo HH, Yapijakis $\mathrm{C}$, editors. Waste treatment in the process industries illustrated ed. CRC Press; 2006.p. 453-497.

2. Thompson G, Swain J, Kay M, Forster CF. The treatment of pulp and paper mill effluent: a review. Bioresour technol. 2001; 77(3):275-286.

3. Smook GA. Handbook for Pulp \& Paper Technologists. Vancouver: Angus Wilde Publications; 1992.

4. Choudhary SK, Jha AN, Srivastava DK. Effect of paper mill effluent on seed germination and seedling growth of maize. Environ Ecol. 1987; 5: 285-287.

5. Pokhrel D, Viraraghavan T. Treatment of pulp and paper mill wastewater-a review. Sci Total Environ. 2004; 333(1):37-58.

6. Kierkegaard A, Renberg L. Chemical characterization of organochlorine compounds, originating from pulp 
mill effluents, in fish. Water Sci Technol. 1988; 20(2): 165.

7. Dural M, Goksu ML, Ozak AA, Baris D. Bioaccumulation of some heavy metals in different tissues of Dicentrarchus labrax L, 1758, Sparus aurata L, 1758 and Mugil cephalus L, 1758 from the Camlik lagoon of the eastern cost of mediterranean (turkey). Environ Monit Assess. 2006; 118(1-3):65-74.

8. Agah H, Leermakers M, Elskens M, Rez FSM, Willy B. Accumulation of trace metals in the muscle and liver tissues of five fish species from the Persian Gulf. Environ Monit Assess. 2009; 157(1-4):499-514.

9. Malik N, Biswas AK, Qureshi TA, Borana K, Virha R. Bioaccumulation of heavy metals in fish tissues of a freshwater lake of Bhopal. Environ Monit Assess. 2010; 160(1-4):267-276.
10. Pompe-Gotal J, Crnic AP. Cadmium in tissues of roe deer (Capreolus capreolus) in Croatia. Veterinarski arhiv 2002; 72(6):303-310.

11. Carneiro J. Basic Histology: Text \& Atlas. Lange Medical Books, McGraw-Hill, Medical Pub. Division; 2003.

12. Ortiz LT, Alzueta C, Trevino J, Castano M. Effects of faba bean tannins on the growth and histological structure of the intestinal tract and liver of chicks and rats. Br Poult Sci. 1994; 35(5):743-754.

13. Emiola IA, Ologhobo AD, Gous RM. Performance and histological responses of internal organs of broiler chickens fed raw, dehulled, and aqueous and dryheated kidney bean meals. Poult Sci. 2007; 86(6):1234-1240. 